multimedia technologies. According to the answers, they like the lessons using computer technologies because these teaching methods provide a variety of exercises and activities. The difficulty arose with self-discipline and consisted in the fact that not all students could approach the learning process with due responsibility, knowing that they themselves decide what to teach and when. From this we can conclude that when teaching a foreign language at a university it is advisable to combine traditional teaching methods when the teacher is present in the classroom and controls the process, and innovative ones, such as E-learning. Probably, a special responsibility for conducting such classes should rest with the teacher, who acts not only as a consultant in a particular subject, but also as the organizer of the entire educational process at a new stage as a whole. Its task is to create the conditions for practical mastery of the language for each student, to choose such teaching methods that would allow each student to show their activity and their creativity. The use of multimedia programs at the university does not at all exclude traditional teaching methods, but harmoniously combines them at all stages of training: familiarization, training, application, control. Using a computer can not only greatly increase the effectiveness of training, but also motivate students to further master the English language.

$$
* * *
$$

1. Дополнительная реальность - это будущее? [Электронный ресурс]. - Режим доступа: http://futurosophy.com/technology/dopolnennaya-realnost

2. Что такое дополнительная реальность? [Электронный ресурс]. - Режим доступа: http://arnext.ru

3. Ganapati, Priya. "How it Works: Augmented Reality." Wired. Aug. 25, 2009. http://www.wired.com/gadgetlab/2009/08/total-immersion/

4. Augmented Reality for Learning English: Achievement, Attitude and Cognitive Load Levels of Students * (PDF Download Available). Available from: https://www.researchgate.net/publication/274944196_Augmented_Reality_for_Learning_English_Achiev ement_Attitude_and_Cognitive_Load_Levels_of_Students

5. Mayer, R. E. (2001). Multimedia learning. New York: Cambridge University Press. ISBN 0-52178-749-1.

6. Банарцева А.В., Нечаева А.А. Обучение иностранному языку онлайн: преимущества и недостатки (статья) Вестник Самарского государственного технического университета. Серия: Психологопедагогические науки. 2016. № 3 (31). С. 6-11.

7. Banartseva A.V. New Education Technologies // Proceedings of Final Dissemination Conference of Tempus Flertuv, held at Saratov State Technical University, 2008 - University of Surrey Published PrintClub Company, 2008, 138c. C. 106-110.

8. Banartseva, A.V., and Vlasova I.V.. "Information and Didactic Base for the Formation of General Cultural Competencies of Bachelors of Engineering and Technology by Means of a Foreign Language." Bulletin of the Samara State Technical University, a Series of "Psychological and Pedagogical Sciences", vol. 4, no. 28, 2015, pp. 47-52.

\title{
Vlasova I.V. \\ Holding scientific conferences in a foreign language among students of technical specialties as the main means of interdisciplinary integration
}

Samara State Technical University

(Russia, Samara)

doi: $10.18411 / \mathrm{j}-02-2020-165$

idsp: ljournal-02-2020-165

\section{Abstract}

The article discusses the features of holding a scientific conference in a foreign language among students of technical specialties as the main means of interdisciplinary integration in the educational sphere for the continuous and holistic self-development of a future specialist in the technical field. Attention is focused on the need for holistic application by students of a technical university of knowledge from different fields of science, as well as their ability to transfer basic ideas from one field of science to another.

Key words: interdisciplinary integration; scientific conference; comprehensive training; personal development; competencies, interdisciplinary integration. 
The development of modern scientific knowledge, the emergence of new scientific disciplines has led to the fact that interdisciplinary integration has become one of the most important methodological foundations of the modern educational process. Interdisciplinary integration is based on the idea of integrated learning. As part of an integrated training system, we combine the necessary training material in the right semantic space. It is worth noting that at present, a comprehensive teaching methodology is actively used both in Russia and in many European countries. At the Samara Technical University, student education is organized on the principle of multilateral inclusion of various academic disciplines [1]. In modern Russian education, interdisciplinary integration includes two main problems:

1. The development of student competence in order to form and develop his professionalism.

2. Personal development, personal self-realization and practical application of competencies in a specific field of activity.

The student's personal development in education today is carried out precisely through interdisciplinary integration. The model of a graduate of a modern university includes a set of general and professional competencies, which are designed not only to form a high level of his professionalism, but also become the basis of his self-realization. So, interdisciplinary integration in education today is becoming the basis of personal self-realization and development of a future specialist [2]. Interdisciplinary integration is based on the interpenetration of the content of different academic disciplines and the creation of a single educational space, the potential of which is aimed at building competencies through the use of innovative pedagogical and didactic methods and organizational forms of training [3].

One of the most common forms of interdisciplinary integration is traditional integrated training sessions, such as lectures, seminars, workshops, and academic student conferences. In conducting student scientific conferences, dynamic elements of integration can be used, which, when using certain methods and technologies, allow to obtain high-quality pedagogical results, and most importantly, contribute to the formation of knowledge of the integral type. [4]

So, we will consider a scientific conference of students of a technical university as a means of interdisciplinary integration in the educational environment for the continuous and holistic self-development of a future specialist in the technical field. It is known that a scientific student conference is a form of scientific activity in which interdisciplinarity of educational activity is realized, due to the fact that:

- holding a scientific conference is aimed at developing the creative activities of students, which cannot be realized without the use of knowledge and skills within the framework of their future specialty;

- participation in the conference is aimed at identifying the presence of various phenomena, processes, which in the future, with in-depth analysis and study, can be generalized in the form of laws, principles and laws;

- in preparation for the conference, a new topic is being developed, therefore there is a lack of information, uncertainty in the direction of the search and the absence of a given algorithm of success requirements, as a result - it is possible to use different ways to achieve the goal [5].

Participation in conferences helps students to develop abilities for experimental research, to identify skills for presenting results in research activities [6, 7]. Holding an annual student conference at the Department of Foreign Languages of the Samara Technical University is an important form of scientific life, the skill of participation in which should be developed already at the university.

It should be noted that the availability of publications or presentations at the conference is a prerequisite for the further continuation of a scientific career, for example, for entering graduate school.

In addition, the conference is a means of communication between people. We propose to consider the objectives of the scientific-student conference: 
1. The development of the intellectual potential of students.

2. The study and discussion of innovative methods for solving the problem, the results of their practical implementation.

3. Mutual exchange of accumulated information and ideas, the search for unsolved problems and their joint solution.

Undoubtedly, the main purpose of holding scientific conferences in a foreign language is to develop the intellectual potential of students, to identify and support talented youth. The main objectives of the conference:

1. Increasing the motivation of students to learn foreign languages.

2. Formation of a new level of language competence: improving the skill of public speaking in a foreign language.

3. Formation of interdisciplinary professional mobility.

Student preparation for participation in a scientific conference is carried out in stages:

1. The student determines the topic of his research with the teacher. During this stage, various articles and innovations are discussed. The teacher tries to orient the student in the chosen direction, since participation in the conference requires conducting student research. He uses the time provided to study literature on a selected topic and conduct scientific and practical research.

2. The teacher helps students to edit the essay, the selection of the necessary scientific vocabulary on the chosen topic.

The process of such work effectively helps students to understand the structure of a foreign language sentence, the correct use of tenses, prepositions and other grammatical phenomena of the language being studied. In the process of preparing the report, students read literature in a foreign language from authentic sources, thereby increasing the level of knowledge and skills in translating scientific and technical literature in their specialty. The speaker should be well versed in the information presented, as he will have to answer questions from the participants and organizers of the conference.

It should be noted that for several years the reports of the conference participants were more abstract in nature. Recently, the conference organizers have proposed to give the conference a more scientific character, that is, a student preparing to make a presentation needs to conduct a small scientific study on his chosen topic of the report. Sometimes such reports can serve as the beginning of a future diploma, and then a dissertation.

Consider the participation in a research conference of a student of the Faculty of Engineering, who presented a report on the topic "Detonation engines in rocket science", where he considered the possibility of using experimental adaptations of pulsed engines in the space industry of aviation. Analyzing the principle of operation of various designs of these engines, he deduced the possibility of their use in an airless environment to obtain the best characteristics at the launch of a launch vehicle. The study consisted of observing existing models in a vacuum space and designing their own models of a detonation engine that would be fully adapted to space travel. He also conducted a comparison of rocket engines of a different operating principle (liquid/solid fuel) and a search for the advantages and disadvantages of this comparison. For a better understanding of the detonation engine itself, a theoretical calculation was given in adaptation for a non-specialist in rocket science. According to the results of the analysis, the student found that detonation engines have a real potential in rocket science, the disclosure of which is still hindered by some structural solutions for air aviation that are not available in a vacuum (resonant ring of nozzles). The student ended his speech with a debriefing and several conclusions of his own, which are based on the materials of the work and are possible scenarios of the final development of the engine for space travel. This report aroused great interest among the participants and organizers of the conference. This was facilitated not only by the content of the report, but also by an interesting presentation of the material, competent speech and the ability to answer questions from the audience. 
Thus, taking into account the fact that interdisciplinary integration is a necessary process of modern education, we came to the conclusion that the active participation of students of a technical university in a scientific conference in a foreign language is an effective means of interdisciplinary integration in the educational sphere for continuous and holistic self-development of a future specialist in the technical field. In the training of future specialists in the technical field for a teacher, it is important to develop the ability of students to apply knowledge from different fields in a comprehensive manner, as well as the ability to transfer basic ideas from one field of science to another, which is also facilitated by students' research work and their active participation in scientific conferences [8].

$$
* * *
$$

1. Afanasyeva O. Yu. Communicative education of students of pedagogical universities based on the idea of interdisciplinarity // Pedagogical education and science. 2006. No. 2. p. 24-28.

2. Vishnyakova E. G. Interdisciplinary network educational and methodological complex as a means of increasing the effectiveness of training at a university: abstract diss. ... to ped. Volgograd, 2007. p.23.

3. Vlasova IV. The use of interdisciplinary integration in the system of formation of general cultural competencies in students of chemical specialties of a technical university // Modern problems of social sciences and humanities: Sat. reports of the 1st All-Russian scientific and practical correspondence conference. Kazan: Fatherland, 2015.p. 60-63.

4. Krivorotova T. A. Integration as a factor in the development of a new quality of education // Economics. Right. Education: a regional aspect. Nizhny Novgorod: Publishing House Gladkova O.V., 2010.p. 233238.

5. Krivorotova T. A. The socio-cultural nature of educational processes through the prism of modernization of social and humanitarian knowledge // Education. Economy. Law: the transformation process and performance criteria: materials of the VII international scientific conference. M .: MIEMP, 2011.p. 481482.

6. Skorikova T. P. Fundamentals of the culture of scientific speech in the system of university training of a modern specialist // Speech communication: specialized bulletin. 2002. Issue. 4 (12). p. 184-187.

7. Chernenko N. M. The concept of scientific communication: the generation of information texts // Classical linguistic education in the modern multicultural space: materials of an international scientific conference. Pyatigorsk: Pyatigorsk Linguistic University, 2004.p. 108 - 113.

8. Shestakova L. A. Formation of a fund of assessment tools in the process of interdisciplinary integration in a modern university // Bulletin of the Nizhny Novgorod State Technical University. R. E. Alekseeva. Series "Management in social systems. Communicative technologies. " 2012. No. 4. p. 102-109.

\section{Grishchenko E.G. \\ Modern professional standards: impulse to self-development or "Vice" for the teacher?} Belgorod National Research University (Russia, Belgorod)

doi: $10.18411 / \mathrm{lj}-02-2020-166$

idsp: ljournal-02-2020-166

\section{Аннотация}

В статье рассматриваются актуальные вопросы, касающиеся современных профессиональных стандартов в области образования. По мнению автора, сегодня на первый план выходят не личностные качества работников образования, а их умения в области применения современных технологий, работы с разными группами детей, знания иностранных языков, что зачастую не совсем оправдано. Автор, поднимая проблему завышенных требований, которые современные профессиональные стандарты предъявляют к учителям, говорит о том, что данные запросы государства ставят перед педагогами порой невыполнимые задачи, тем самым усложняя организацию образовательного процесса.

Ключевые слова: педагог, учитель, компетентность, образовательные стандарты, профессиональные требования 